Państwo i Społeczeństwo

2017 (XVII) nr 4

e-ISSN 2451-0858

ISSN 1643-8299

Paweł Szymanowski ${ }^{1}$, Hanna Szweda ${ }^{1}$, Wioletta Katarzyna Szepieniec ${ }^{1}$, Marcin Zarawski ${ }^{1}$, Ewelina Malanowska ${ }^{2}$, Elżbieta Świśs ${ }^{1}$, Marcin Jóźwik ${ }^{3}$

1. Krakowska Akademia im. Andrzeja Frycza Modrzewskiego, Wydział Lekarski i Nauk o Zdrowiu, Klinika Ginekologii i Uroginekologii

2. Pomorski Uniwersytet Medyczny w Szczecinie,

Klinika Ginekologii, Endokrynologii i Onkologii Ginekologicznej

3. Uniwersytet Warmińsko-Mazurski w Olsztynie, Wydział Lekarski Collegium Medicum, Katedra Ginekologii i Położnictwa, Klinika Ginekologii

\title{
ROLA DEFEKTU APIKALNEGO W PATOGENEZIE OBNIŻENIA NARZĄDÓW MIEDNICY MNIEJSZEJ: CYSTOCELE Z DEFEKTEM APIKALNYM
}

\author{
Autor korespondencyjny: \\ Paweł Szymanowski, Krakowska Akademia im. Andrzeja Frycza Modrzewskiego, \\ Wydział Lekarski i Nauk o Zdrowiu, Klinika Ginekologii i Uroginekologii, \\ ul. G. Herlinga-Grudzińskiego 1, 30-705 Kraków \\ e-mail: pszymanowski@afm.edu.pl
}

\section{Streszczenie}

Wprowadzenie: W uroginekologii, zarówno w literaturze, jak i w pracy klinicznej, stosowane są różne systemy oceny obniżenia narządów dna miednicy. Powoduje to trudności $\mathrm{w}$ planowaniu leczenia, jak również w ocenie skuteczności stosowanych metod operacyjnych. Do obiektywnej oceny stopnia zaburzeń statyki narządu płciowego służy skala POP-Q (Pelvic Organ Prolapse Quantification). Nie informuje ona jednak o rodzaju defektu. Z kolei podział kliniczny według DeLancey definiuje rodzaj defektu, wskazując anatomiczną przyczynę uszkodzenia, ale nie stopień jego nasilenia. Nie uwzględnia również pojęcia „cystocele z defektem apikalnym”. 
Materiał i metody: Autorzy zbadali 96 pacjentek, które zgłaszały się celem kwalifikacji do leczenia z powodu objawowego obniżenia narządów miednicy mniejszej. Zastosowano nowy, standaryzowany sposób badania uroginekologicznego. Badanie uwzględniało rodzaj defektu i stopień jego nasilenia na każdym z trzech poziomów dna miednicy.

Wyniki: Ten sposób badania pozwolił zidentyfikować zarówno znane już cystocele z defektem środkowym i bocznym, jak również nieopisywane dotychczas cystocele z defektem apikalnym i mieszanym.

Wnioski: Autorzy proponują nowy sposób badania uroginekologicznego z jednoczesnym zastosowaniem skali POP-Q i zmodyfikowanej klasyfikacji obniżenia narządów miednicy mniejszej według DeLancey, uwzględniającej wpływ defektu na poziomie I, czyli defektu apikalnego, na obniżenie na poziomie II. Wydaje się, iż taki sposób postępowania daje możliwość skuteczniejszego planowania zabiegów uroginekologicznych, ograniczając jednocześnie odsetek wznów.

Słowa kluczowe: choroby uroginekologiczne, obniżenie narządów miednicy, defekt apikalny, cystocele

\section{Wprowadzenie}

Cystocele, czyli obniżenie pęcherza moczowego i przedniej ściany pochwy, jest najczęstszą formą obniżenia narządów miednicy mniejszej [1]. Jest to również defekt o największej częstości nawrotów po leczeniu operacyjnym [2]. Defekt apikalny jest zdefiniowany jako obniżenie szyjki macicy lub kikuta pochwy po wykonanej histerektomii. Częstość występowania defektu apikalnego nie jest dokładnie znana, zależy od analizowanej populacji kobiet i zastosowanych metod badawczych.

Stopień obniżenia pęcherza moczowego oraz innych narządów miednicy mniejszej jest opisywany przy użyciu systemu Pelvic Organ Prolapse Quantification (POP-Q) [3]. Podział ten wyróżnia następujące stopnie:

- stopień 0 - bez obniżenia;

- stopień 1 - część prowadząca obniżenie więcej niż $1 \mathrm{~cm}$ ponad strzępkami błony dziewiczej;

- stopień 2 - część prowadząca obniżenie pomiędzy $1 \mathrm{~cm}$ powyżej, a $1 \mathrm{~cm}$ poniżej strzępków błony dziewiczej;

- stopień 3 -część prowadząca obniżenie więcej niż $1 \mathrm{~cm}$ poniżej strzępków błony dziewiczej, ale nie więcej niż $2 \mathrm{~cm}$ mniej, niż całkowita długość pochwy w $\mathrm{cm}$;

- stopień 4 - wypadanie na długości całej pochwy.

Skala POP-Q jest najczęściej stosowana w badaniach naukowych i literaturze fachowej dotyczącej obniżenia narządów miednicy mniejszej, nie określa ona jednak rodzaju uszkodzonych struktur, a jedynie stopień nasilenia defektu.

Ze względów praktycznych podczas planowania leczenia operacyjnego stosuje się częściej podział kliniczny według DeLancey. 
Klasyfikuje on następujące poziomy defektów w miednicy mniejszej:

- poziom I - uszkodzenie w obrębie więzadeł krzyżowo-macicznych, obszar enterocele, obniżenie macicy, szyjki macicy lub kikuta pochwy;

- poziom II - uszkodzenie powięzi pęcherzowo-pochwowej lub odbytniczo-pochwowej, obszar cysto- i rectocele;

- poziomie III - uszkodzenie struktur więzadłowych podtrzymujących cewkę moczową, obszar uretrocele.

W obrębie przedniego poziomu II wyróżnia się uszkodzenie środkowe powięzi pęcherzowo-pochwowej, charakteryzujące się gładką ścianą cystocele, oraz uszkodzenie boczne powięzi pęcherzowo-pochwowej z zachowaniem marszczek pochwy (rugae vaginales) [4].

Częstość nawrotów po leczeniu operacyjnym obniżenia narządów miednicy mniejszej poprzez plastykę przedniej ściany pochwy, gdzie do rekonstrukcji używa się własnej tkanki (powięzi pęcherzowo-pochwowej), wynosi 30\% po roku obserwacji, a są również prace raportujące około 50\% nawrotów. Fakt ten nie pozwala na traktowanie plastyki przedniej jako głównej metody leczenia cystocele [17].

Autorzy niniejszego opracowania są zdania, że wysoka liczba nawrotów wynika prawdopodobnie nie tyle z niedoskonałości samej techniki operacyjnej, ile przede wszystkim z nieprawidłowej kwalifikacji pacjentek do leczenia operacyjnego. Kwalifikacja do leczenia operacyjnego powinna uwzględniać zarówno nasilenie defektu (skala POP-Q), jak i miejsce uszkodzenia (podział kliniczny według DeLancey). Dzięki takiemu kompleksowemu podejściu terapia staje się leczeniem przyczynowym, a nie jedynie objawowym.

W niniejszej pracy Autorzy proponują technikę badania uroginekologicznego z zastosowaniem skali POP-Q oraz zmodyfikowanego podziału klinicznego według DeLancey, uwzględniającą udział defektu na poziomie I w obniżeniu narządów miednicy mniejszej na poziomie II. Uwzględnienie defektu apikalnego w sposób znaczący wpływa na decyzje kliniczne, ponieważ zmienia wybór metody operacyjnej w leczeniu obniżenia narządów miednicy mniejszej na metodę ukierunkowaną na naprawę anatomicznej przyczyny danego defektu, a nie jego prezentacji klinicznej.

Zauważono, że defekt na poziomie I koreluje często z obniżeniem pęcherza moczowego widocznym jako cystocele, a operacja naprawcza $\mathrm{w}$ zakresie defektu na poziomie I powoduje zmniejszenie dolegliwości związanych z pęcherzem nadaktywnym u $1 / 3$ pacjentek [4]. Ponadto wybór techniki operacyjnej ukierunkowanej na leczenie defektu, a nie prezentacji klinicznej zmniejsza częstość nawrotów do 3,7\% w dwuletnim okresie obserwacji.

Często stosowaną w Polsce metodą leczenia defektu na poziomie I według DeLancey jest histerektomia z plastyką pochwy lub bez. Wydaje się, że takie podejście nie ma w dzisiejszych czasach uzasadnienia. Część operatorów zawiesza kikut pochwy do więzadła krzyżowo-kolcowego, zazwyczaj jedno- 
stronnie. Stosuje się również operacje brzuszne z mocowaniem przy pomocy siatek polipropylenowych, które przymocowywane są do promontorium bądź na wysokości S2/S3 do bocznej krawędzi więzadła podłużnego przedniego na kości krzyżowej. Obecnie przyjętą metodą leczenia defektu na poziomie I jest cerwikosakropeksja, histerosakropeksja lub kolposakropeksja. Standardowym postępowaniem w przypadku obniżenia macicy na skutek defektu na poziomie I wydaje się laparoskopowe, nadszyjkowe usunięcie trzonu macicy z jednoczasowym zawieszeniem szyjki do kości krzyżowej na wysokości S2/S3 lub do promontorium $[2,5,6]$.

Proponowana $\mathrm{w}$ niniejszej pracy metoda badania uroginekologicznego u pacjentek z obniżeniem narządów miednicy mniejszej pozwala na dokładne zidentyfikowanie przyczyny defektu, co umożliwi przeprowadzanie operacji dedykowanych konkretnemu defektowi. Można oczekiwać, że da to lepsze rezultaty w prospektywnej ocenie wyników leczenia. Często nieprawidłowo przeprowadzane badania uroginekologiczne - i idąca za tym błędna kwalifikacja pacjentek do dalszego leczenia operacyjnego zaburzeń statyki - wskazują na potrzebę stworzenia wystandaryzowanej techniki badania.

\section{Materiał i metody}

\section{Grupa badana}

W pilotażowym badaniu z zastosowaniem opisywanej poniżej techniki oceny uroginekologicznej wzięło udział 96 pacjentek Oddziału Klinicznego Ginekologii i Uroginekologii (Wydział Lekarski i Nauk o Zdrowiu Krakowskiej Akademii im. Andrzeja Frycza Modrzewskiego), które zgłaszały się celem kwalifikacji do leczenia z powodu objawowego obniżenia narządów miednicy mniejszej w latach 2015-2017. Wiek pacjentek wynosił od 20 do 87 lat (średnio 54,6 $\pm 3,2$ ), liczba porodów od 0 do 10 (średnio 2), BMI wynosiło od 19 do 35 (średnio 25).

\section{Metoda badania uroginekologicznego}

W celu przeprowadzenia badania uroginekologicznego proponowaną techniką pacjentka ułożona jest na fotelu ginekologicznym w pozycji litotomijnej przy średnio wypełnionym pęcherzu moczowym (około $200 \mathrm{ml}$ ). Badanie rozpoczyna się oceną sromu i krocza w spoczynku i podczas parcia. Następnie, używając wziernika dwułyżkowego Kristellera, ocenia się kolejno:

- przy użyciu tylnej łyżki - kompartyment przedni, poziom II - badanie cystocele i poziom III w zakresie uretrocele;

- przy użyciu przedniej łyżki - kompartyment tylny, poziom II - badanie rekto- lub enterocele;

- przy użyciu obu łyżek - kompartment środkowy - badanie defektu apikalnego. 
W przypadku stwierdzenia cystocele należy dodatkowo ocenić rodzaj uszkodzenia, które może prezentować się jako boczne lub środkowe. Dla cystocele $\mathrm{z}$ uszkodzeniem bocznym, gdzie powięź pęcherzowo-pochwowa ulega jedno- lub obustronnemu oderwaniu od kości łonowej, charakterystyczne jest zachowanie marszczek pochwy (rugae vaginales), podczas gdy w przypadku cystocele $\mathrm{z}$ defektem centralnym marszczek nie stwierdza się.

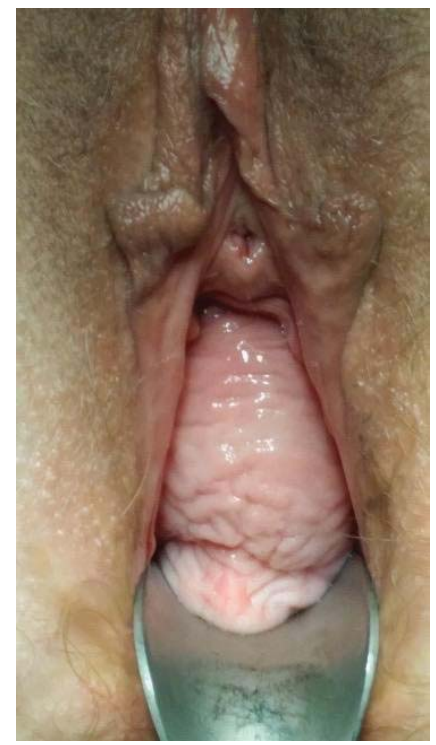

Rycina 1. Defekt boczny, w którym doszło do oderwania powięzi pęcherzowo-pochwowej od kości łonowych

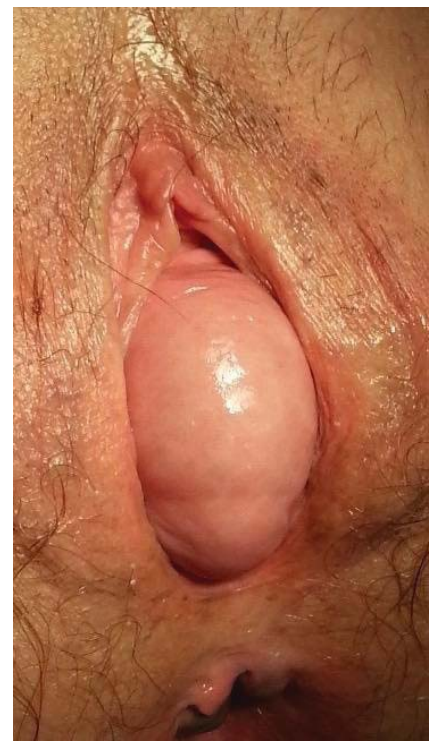

Rycina 2. Defekt centralny, w którym rozciągnięciu uległa powięź pęcherzowo-pochwowa pod pęcherzem moczowym

Następnie, po wprowadzeniu obydwu łyżek wziernika, które podczas parcia pacjentki powoli wysuwa się z pochwy, ocenia się położenie punktu referencyjnego dla poziomu I. Jako punkt referencyjny autorzy ustalili kikut pochwy w przypadku pacjentek po histerektomii lub granicę sklepień przedniego i tylnego pochwy z częścią pochwową szyjki macicy. Ten sposób pozwala ocenić defekt na poziomie I.

W przypadku stwierdzenia defektu na poziomie I konieczne jest wprowadzenie łyżki tylnej wziernika, która reponuje prowadzącą część obniżenia spowodowaną tym defektem. Po zniwelowaniu defektu na poziomie pierwszym konieczna jest ocena ewentualnych zmian prezentacji w cystocele. Możliwe jest jego całkowite zaniknięcie, jeżeli przyczyną cystocele jest izolowany defekt na 
poziomie I, lub jego zmniejszenie, jeżeli przyczyną powstania cystocele jest defekt mieszany na poziomie I i II. Defekt na poziomie III, zazwyczaj słabo wyrażony anatomicznie, a skutkujący zaburzeniami mechanizmu zamykania cewki moczowej, nie był przedmiotem analizy tego badania.

Badanie uroginekologiczne uzupełniono sonografią transwaginalną z zastosowaniem dodatkowo metod znanych w piśmiennictwie anglosaskim jako pelvic floor sonography i introitus sonography [14]. Metody ultrasonograficzne w uroginekologii są dobrze opisane i stosowane w proponowanej metodzie badania głównie celem uzupełnienia oceny defektu poziomu II.

W ocenie obniżenia znajduje zatem zastosowanie skala POP-Q do oceny stopnia obniżenia części przodującej, z jednoczesnym użyciem zmodyfikowanej skali DeLancey, która podaje lokalizację defektu. W dokumentacji badania uroginekologicznego należy uwzględnić wszystkie poziomy z użyciem skali POP-Q i zmodyfikowanej skali DeLancey.

\section{Wyniki}

Tabela 1. Częstość poszczególnych rodzajów obniżenia narządów dna miednicy mniejszej u kobiet (grupa badana: pacjentki Oddziału Klinicznego Ginekologii i Uroginekologii, Wydział Lekarski i Nauk o Zdrowiu Krakowskiej Akademii im. Andrzeja Frycza Modrzewskiego, n=96)

\begin{tabular}{cccc}
\hline $\begin{array}{c}\text { Rodzaj } \\
\text { obniżenia }\end{array}$ & $\begin{array}{c}\text { Częstość } \\
\text { występowania }\end{array}$ & $\begin{array}{c}\text { Cystocele } \\
\text { centralne }\end{array}$ & $\begin{array}{c}\text { Cystocele } \\
\text { lateralne }\end{array}$ \\
\hline Izolowany defekt apikalny & $10,42 \%$ & - & - \\
Cystocele & $50 \%$ & $14,58 \%$ & $85,42 \%$ \\
Cystocele mieszane & $36,46 \%$ & $5,72 \%$ & $94,28 \%$ \\
Cystocele z defektem apikalnym & $3,12 \%$ & - & - \\
\hline
\end{tabular}

W grupie badanej u 10 pacjentek $(10,42 \%, \mathrm{p}<0,05)$ stwierdzono izolowany defekt apikalny (defekt poziomu I). Cystocele, czyli obniżenie pęcherza spowodowane uszkodzeniem powięzi pęcherzowo-pochwowej stwierdzono u 48 pacjentek $(50 \%, \mathrm{p}<0,05)$. U 7 pacjentek $(7,29 \%, \mathrm{p}<0,05)$ stwierdzono cystocele $\mathrm{z}$ defektem środkowym, a u 41 pacjentek $(42,7 \%, \mathrm{p}<0,05)$ - z defektem bocznym. Cystocele $\mathrm{z}$ defektem środkowym występuje zatem u $14,58 \%$ procent pacjentek z cystocele, a cystocele z defektem bocznym u 85,42\% pacjentek. Mieszane cystocele spowodowane współistniejącym defektem na poziomie I i II stwierdzono u 35 badanych osób $(36,46 \%, p<0,05)$, przy czym w tej grupie defekt boczny na poziomie II stwierdzono u 33 osób $(34,37 \%, \mathrm{p}<0,05)$, a mieszane cystocele $\mathrm{z}$ defektem środkowym na poziomie II - tylko u 2 osób $(2,08 \%$ p $<0,05)$. Zatem 
u pacjentek z cystocele spowodowanym współistniejącym defektem na poziomie I i II, aż w 94,28\% $(\mathrm{p}<0,05)$ przypadków występował defekt boczny w obrębie poziomu II. Cystocele uwarunkowane wyłącznie defektem apikalnym wystąpiło u 3 pacjentek $(3,12 \%, \mathrm{p}<0,05)$ (Ryc. 3$)$.

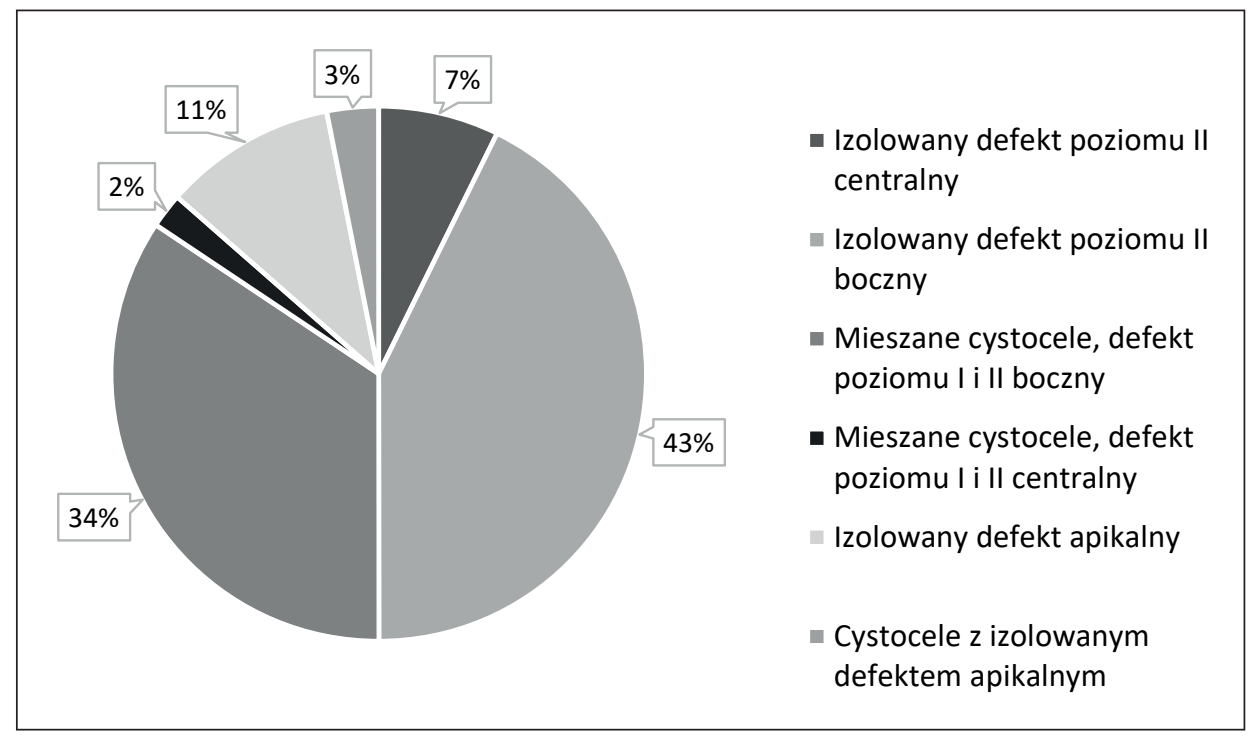

Rycina 3. Częstość poszczególnych rodzajów obniżenia narządów miednicy mniejszej w badanej grupie kobiet

Technika badania uroginekologicznego proponowana przez autorów umożliwia podział na cystocele uwarunkowane izolowanym defektem apikalnym (poziom I), cystocele uwarunkowane izolowanym defektem na poziomie II (z defektem bocznym lub środkowym) oraz cystocele $\mathrm{z}$ defektem mieszanym na poziomie I i II. Taki sposób badania pozwala zróżnicować trzy główne rodzaje cystocele:

1. cystocele z izolowanym defektem na poziomie II - tylko defekt środkowy lub boczny;

2. cystocele z izolowanym defektem na poziomie I - tylko defekt apikalny,

3. cystocele $z$ defektem mieszanym (defekt apikalny w połączeniu z defektem środkowym lub bocznym na poziomie II). 


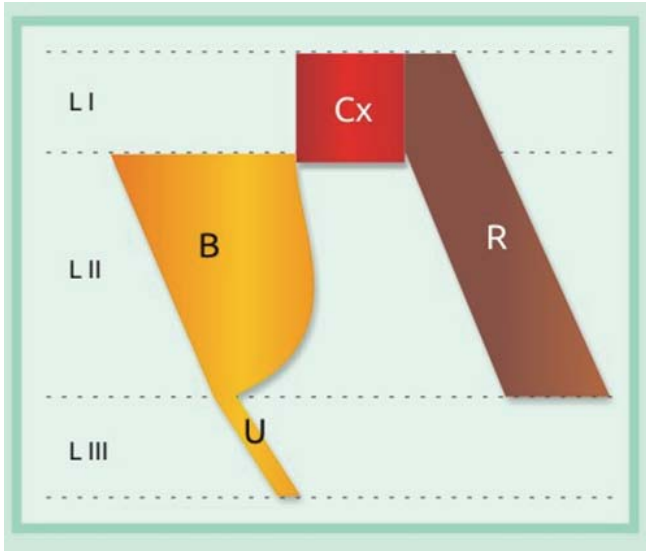

Rycina 4. Cystocele z defektem na poziomie II

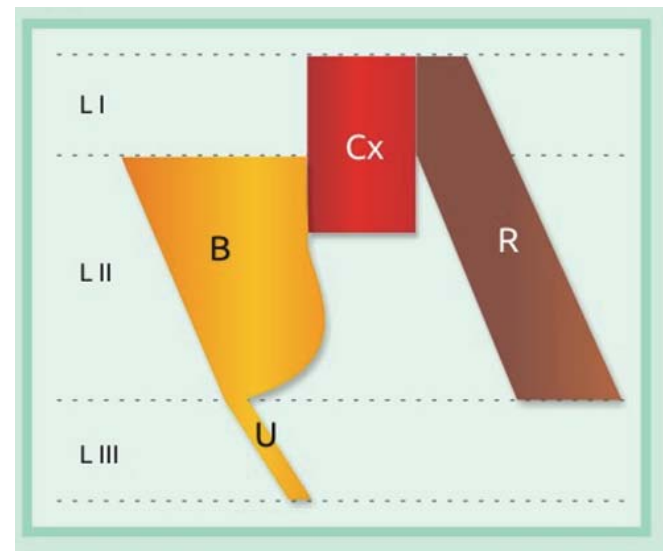

Rycina 5. Cystocele z defektem apikalnym

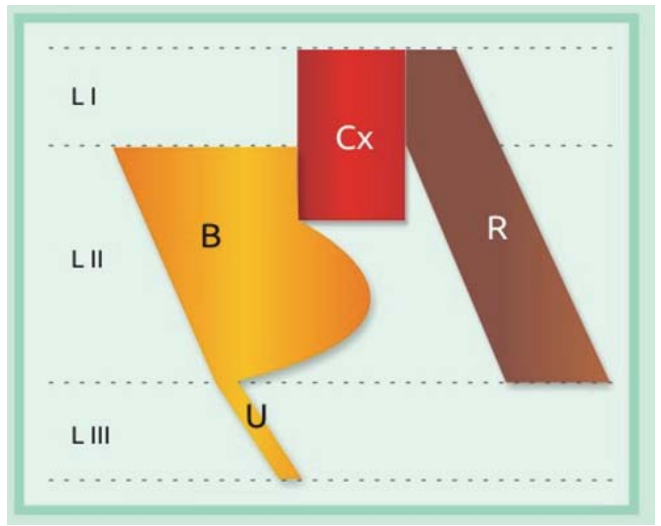

Rycina 6. Cystocele z defektem mieszanym 


\section{Dyskusja}

Grupa pacjentek, u których główną przyczyną dolegliwości jest izolowany defekt na poziomie I (który w pobieżnym badaniu ginekologicznym może wyglądać identycznie jak defekt na poziomie II), nie odniesie korzyści z leczenia techniką operacyjną ukierunkowaną na naprawę defektu na poziomie II. Niestety często w takich przypadkach stosowana jest plastyka przedniej ściany pochwy, czyli operacja dedykowana defektom środkowym w obrębie powięzi pęcherzowo-pochwowej. Oznacza to, że nie jest to w przypadku tej grupy pacjentek leczenie przyczynowe i nie zapewni ono długoterminowej poprawy. Także obniżenie macicy będące skutkiem uszkodzenia aparatu więzadłowego na poziomie I nie może być skutecznie leczone poprzez histerektomię. Usunięcie macicy nie naprawia uszkodzonych więzadeł krzyżowo-macicznych i w krótkim czasie można oczekiwać obniżenia lub wypadania szczytu pochwy.

Wydaje się, że wysoki poziom nawrotów, szczególnie po operacjach z dostępu pochwowego, takich jak plastyka przednia, gdzie odsetek udanych operacji oscyluje w granicach 30-70\% [16,17], spowodowany może być niedostatecznym uwzględnieniem defektu apikalnego oraz brakiem różnicowania defektów bocznych i środkowych w obrębie poziomu II w kompartmencie przednim w procesie planowania operacji. Niska skuteczność plastyki przedniej nie może dziwić, skoro tylko u około 7\% pacjentek stwierdzono cystocele z defektem środkowym, a $2 \%$ pacjentek miało cystocele mieszane z łączonym defektem apikalnym oraz defektem środkowym na poziomie II. Mimo iż wielu autorów zauważa wysoką korelację defektu apikalnego z cystocele lub zmniejszenie cystocele po korekcji defektu apikalnego, to obserwacja ta niezmiernie rzadko zostaje wykorzystana w procesie planowania leczenia operacyjnego. W obszarze zainteresowań wielu badaczy znajduje się cystocele, które po korekcji defektu na poziomie I nie wymaga korekcji defektu na poziomie II. Wydaje się, że liczba nawrotów cystocele jest zdecydowanie większa w przypadku braku pierwotnej podpory na poziomie I.

Rooney i wsp. wykazali, że większość przypadków obniżenia przedniej ściany pochwy skorelowana jest ściśle z obniżeniem szczytu pochwy, czyli defektem apikalnym [8]. Ta grupa pacjentek nie odniesie korzyści z leczenia operacyjnego techniką naprawiającą defekt na poziomie II.

Także inni badacze analizujący procedury operacyjne w zakresie naprawy dna miednicy doszli do wniosku, że występowanie defektu apikalnego jest mocno skorelowane z obniżeniem przedniej ściany pochwy oraz średnio - z obniżeniem tylnej ściany pochwy. Ich zdaniem większość obniżeń przedniej ściany pochwy wymaga korekcji w zakresie defektu apikalnego $[8,10]$. Jest to zgodne $\mathrm{z}$ obserwacją autorów niniejszego opracowania. W przedstawionym badaniu u około $50 \%$ pacjentek z obniżeniem narządów miednicy mniejszej wykazany został udział defektu apikalnego w powstaniu obniżenia. U tych pacjentek nieodzowna jest naprawa defektu na poziomie I. Uwzględnienie defektu apikalnego 
w planowaniu operacji prawdopodobnie pozwoli w przyszłości znacznie ograniczyć liczbę wznów.

Także Hsu i wsp. wykazali, że cystocele w około 77\% przypadków wynika z istnienia defektu apikalnego, co tylko potwierdza, że musi on być brany pod uwagę podczas planowania zabiegów korygujących obniżenie narządów miednicy mniejszej [11]. Różnice rozkładu defektów w porównaniu z badaniem własnym mogą wynikać $\mathrm{z}$ doboru grup badawczych w obrębie różnych regionów geograficznych. Różnice te uwarunkowane mogą być zarówno innym stylem życia, jak i czynnikami genetycznymi. Z kolei Wu i wsp. udowodnili, że u pacjentek z obniżeniem narządów miednicy mniejszej, które zostały zoperowane bez korekcji defektu apikalnego, wykonywano ponownie więcej korekcji w obrębie przedniego kompartmentu, co wynikało zdaniem autorów z nierozpoznania defektu apikalnego jako czynnika etiologicznego obniżenia przedniego kompartmentu [13].

Często stosowaną w Polsce i Europie metodą z wyboru przy obniżeniu lub wypadaniu macicy jest histerektomia, która nie jest sposobem leczenia defektu apikalnego, gdyż tegoż defektu nie niweluje [12]. Co więcej, w trakcie histerektomii dochodzi do odcięcia więzadeł krzyżowo-macicznych, co może stanowić jatrogenne podłoże do powstania obniżenia lub wypadania kikuta pochwy w przyszłości.

U pacjentek z defektem na poziomie I autorzy proponują techniki operacyjne bazujące na fiksacji macicy (szyjki macicy lub kikuta pochwy u pacjentek po histerektomii) do kości miednicy. Metody takie jak histerosakropeksja, cerwikosakropeksja czy kolpopeksja wykonywane mogą być techniką laparoskopową lub drogą laparotomii. W operacjach przezpochwowych stosować można alternatywnie fiksację krzyżowo-kolcową. Wybór odpowiedniej metody operacyjnej zależy w dużej mierze także od innych niż sam defekt czynników, takich jak wiek pacjentki, inne obciążenia czy możliwości ośrodka, w którym wykonywana jest operacja. W przypadku izolowanego defektu na poziomie II istotne w wyborze techniki operacyjnej jest różnicowanie defektu środkowego i bocznego. Tylko w przypadku defektu środkowego wskazana jest plastyka przednia. W przypadku defektu bocznego stosowane są plastyki z użyciem materiału alloplastycznego u pacjentek pomenopauzalnych oraz tzw. naprawa boczna (lateral repair) u przedmenopauzalnych. W przypadku defektów na poziomie I i II należy stosować techniki łączone w zależności od stopnia nasilenia występujących defektów. Biorąc pod uwagę przytoczone fakty, wydaje się, że proponowany przez autorów system oceny obniżenia narządów miednicy mniejszej, a w szczególności cystocele, może stanowić narzędzie umożliwiające przyczynowe planowanie leczenia operacyjnego.

Można mieć nadzieję, iż takie podejście wpłynie na zmniejszenie liczby wznów w przyszłości. Autorzy widzą konieczność przeprowadzenia prospektywnych badań analizujących wznowy po operacjach naprawczych, do których wskazania określano by, korzystając z proponowanego systemu badania uroginekologicznego. 
Konieczność uwzględniania defektu apikalnego w planowaniu zabiegów operacyjnych i zasadność jego naprawy wykazało również badanie Kantartzisa i wsp. [9]. Porównano 1358 operacji z korekcją defektu apikalnego w odniesieniu do 2465 wykonanych histerektomii w przypadku wypadania narządu rodnego. Stwierdzono, że przypadki bez pierwotnej korekcji defektu apikalnego korelowały częściej z korekcją cystocele $(23,8 \%$ vs $9,4 \%$, p < 0,001$)$ za to rzadziej z korekcją rectocele $(3,4 \%$ vs $12,2 \%, p<0,001)$ oraz kombinowaną korekcją rectoi cystocele $(16,4 \%$ vs $25,6 \%, \mathrm{p}<0,001)$.

Kolejny argument to około 30-procentowe ryzyko obniżenia narządów miednicy mniejszej, a szczególnie pęcherza po wykonaniu histerektomii. Z tego względu uzasadnione wydaje się wszycie więzadeł krzyżowo-macicznych bocznie w kikut pochwy podczas histerektomii w celu zachowania funkcji aparatu więzadłowego na poziomie I według DeLancey. Także inni autorzy podkreślają rolę podpory szczytu pochwy dla przedniej ściany pochwy poprzez struktury więzadłowe łączące szyjkę z kośćmi miednicy [8].

Dietz i wsp. stwierdzili natomiast, że histeropeksja jest skuteczną terapią w przypadku obniżenia macicy. Liczba nawrotów jest niewielka, a współistniejące cystocele najczęściej nie wymaga dalszej interwencji [10]. Warto zaznaczyć, że celem leczenia jest zlikwidowanie objawów i przywrócenie prawidłowej funkcji miednicy mniejszej i jej narządów. Nie musi to być jednoznaczne z przywróceniem idealnej anatomii narządów (czyli stopnia $0 \mathrm{w}$ skali POP-Q).

Zdaniem autorów w celu poprawienia skuteczności terapii operacyjnej konieczne jest uwzględnianie defektu apikalnego podczas planowania leczenia. Należy również w szerszych badaniach epidemiologicznych określić częstość występowania poszczególnych defektów według zmodyfikowanego podziału DeLancey oraz rozwinąc metody obrazowania defektu apikalnego, w szczególności ultrasonografii i rezonansu magnetycznego. Zdaniem Tunna i wsp. sonografia ma jednak ograniczone znaczenie w ocenie defektu apikalnego [14], natomiast Summers i wsp. zwrócili uwagę na wykazaną w badaniu MR wysoką korelację wypadania przedniego kompartmentu $\mathrm{z}$ utratą podpory apikalnej $(\mathrm{r}=0,73)[15]$.

\section{Wnioski}

Opisany sposób badania z jednoczesnym zastosowaniem skali POP-Q i zmodyfikowanej skali DeLancey do opisu defektu bądź jego braku na poziomie I do III jest narzędziem umożliwiającym wystandaryzowaną ocenę obniżenia narządów miednicy mniejszej.

Wyniki tego pilotażowego badania wskazują na niebagatelny udział defektu apikalnego w nieprawidłowościach statyki narządów miednicy mniejszej u kobiet. Jego nieuwzględnienie podczas kwalifikacji do operacji skazuje dużą grupę pacjentek na nieefektywne leczenie. 


\section{Bibliografia}

1. Hendrix SL, Clark A, Nygaard I, et al. Pelvic organ prolapse in the Women's Health Initiative: gravity and gravidity. Am J Obstet Gynecol. 2002; 186(6): 1160-1166.

2. Shull BL, Bachofen C, Coates KW, et al. A transvaginal approach to repair of apical and other associated sites of pelvic organ prolapse with uterosacral ligaments. Am J Obstet Gynecol. 2000; 183(6): 1365-1373.

3. Bump RC, Mattiasson A, Bo K, et al. The standardization of terminology of female pelvic organ prolapse and pelvic floor dysfunction. Am J Obstet Gynecol. 1996; 175(1): 10-17.

4. Morgan DM, Lewicky-Gaupp C, Dunn RL, et al. Factors associated with urge urinary incontinence after surgery for stress urinary incontinence. Female Pelvic Med Reconstr Surg. 2011; 17(3): 120-124.

5. Park AJ, Paraiso MF. Surgical management of uterine prolapse. Minerva Ginecol. 2008; 60(6): 493-507.

6. Vellucci F, Regini C, Barbanti, et al. Pelvic floor evaluation with transperineal ultrasound: a new approach. Minerva Ginecol. 2017; 10.23736/S00264784.17.04121-1.

7. DeLancey JOL. Anatomic aspects of vaginal eversion after hysterectomy. Am J Obstet Gynecol 1992; 166: 1717-1724.

8. Rooney K, Kenton K, Mueller ER, et al. Advanced anterior vaginal wall prolapse is highly correlated with apical prolapse. Am J Obstet Gynecol. 2006; 195(6): 1837-1840.

9. Kantartzis KL, Turner LC, Shepherd JP, et al. Apical support at the time of hysterectomy for uterovaginal prolapse. Int Urogynecol J. 2015; 26(2): 207-212.

10. Dietz V, de Jong J, Huisman M, et al. The effectiveness of the sacrospinous hysteropexy for the primary treatment of uterovaginal prolapse. Int Urogynecol J Pelvic Floor Dysfunct. 2007; 18(11): 1271-1276.

11. Hsu Y, Chen L, Summers A, et al. Anterior vaginal wall length and degree of anterior compartment prolapse seen on dynamic MRI. Int Urogynecol J Pelvic Floor Dysfunct. 2008; 19(1): 137-142.

12. Walters MD, Ridgeway BM. Surgical treatment of vaginal apex prolapse. Obstet Gynecol. 2013; 121(2 Part 1): 354-374.

13. Wu JM, Kawasaki A, Hundley AF, et al. Predicting the number of women who will undergo incontinence and prolapse surgery, 2010 to 2050. Am J Obstet Gynecol. 2011; 205(3): 230.e1-230.e5; 10.1016/j.ajog.2011.03.046.

14. Tunn R, Albrich S, Beilecke K, et al. Interdisciplinary S2k Guideline: Sonography in Urogynecology. Short version: AWMF Registry Number 015/055; Interdisziplinäre S2k-Leitlinie: Sonografie im Rahmen der urogynäkologischen Diagnostik. Geburtshilfe Frauenheilkd. 2014; 74(12): 1093-1098.

15. Summers A, Winkel LA, Hussain HK, et al. The relationship between anterior and apical compartment support. Am J Obstet Gynecol. 2006; 194: 1438-1443.

16. Houman J, Weinberger JM, Eilber KS. Native tissue repairs for pelvic organ prolapse. Curr Urol Rep. 2017; 10.1007/s11934-017-0648-0.

17. Dietz HP, Hankins KJ, Wong V. The natural history of cystocele recurrence. Int Urogynecol J. 2014; 25(8): 1053-1057 


\title{
The role of the apical defect in the pathogenesis of pelvic organ prolapse: cystocele with apical defect
}

\begin{abstract}
Introduction: In urogynecology, both in subject literature and in clinical work, different systems for the assessment of pelvic organ prolapse are used. The lack of standardization causes difficulties in treatment planning and in the evaluation of the effectiveness of applied surgical methods. The most commonly used scale is the POP-Q System which describes the severity of the prolapse without taking the type of defect into account. On the other hand, the clinical classification by DeLancey defines the type of defect but does not take its severity into account. The latter classification system also does not include cystocele with apical defect.

Material and methods: The authors examined 96 patients presenting for advice of treatment due to symptomatic pelvic floor disease. A new, standardized method of urogycological examination was implemented. The evaluation included the type of defect and its severity at all three pelvic floor levels.

Results: This method of examination allowed the identification of both already known cystocele with middle and lateral defects, as well as not yet described cystocele with apical and mixed defects.

Conclusions: The authors propose a new, standardized method of urogynecological examination which assumes the simultaneous application of the POP-Q System and the modified classification of lower pelvic organ prolapse by DeLancey which also describes the impact of level I defects (apical defects) on level II prolapse. It seems that this approach allows for more effective planning of urogynecological procedures, while reducing the rate of recurrence.
\end{abstract}

$\underline{\text { Key words: }}$ urogynecological diseases; pelvic organ prolapse; apical defect, cystocele 
